\title{
Participation of Children between Three and Five Years Old at Home and in the Community Setting
}

\author{
Sofia Guichard* (1) \& Catarina Grande (1) \\ Universidade do Porto, Porto, Portugal
}

\begin{abstract}
The main goal of the present study was to document the participation of preschool children at home and in the community setting, describing the differences between eligible children with the support of Special Education Service and/or of the Early Intervention System and non-eligible children, in three main dimensions: child functioning, child participation, and perceived environmental barriers. Data about child functioning was collected through preschool teachers and about participation and barriers through parents. Sociodemographic data were also collected. Forty pre-school teachers and 116 children (and their parents) participated in this study. Forty-two children were eligible and had support from Special Education Service and/or of the Early Intervention System. The results showed that eligible children have lower levels of functionality, participate less frequently, and are less involved in the activities at home and the community setting and that their parents perceive more environmental barriers in both settings. The results were analyzed considering the Biopsychosocial Model.
\end{abstract}

KEYWORDS: environmental barriers, social inclusion, participation

\section{A Participação de Crianças entre os Três e os Cinco Anos em Casa e na Comunidade}

\begin{abstract}
RESUMO - O presente estudo tem como objetivo descrever a participação de crianças entre os três e cinco anos de idade em casa e na comunidade, comparando crianças elegíveis e com apoio da Educação Especial e/ou do Sistema Nacional de Intervenção Precoce para a Infância com crianças não elegíveis e sem apoio, em três dimensões: funcionalidade da criança, participação da criança e perceção de barreiras ambientais em ambos os contextos. Os dados acerca da funcionalidade da criança foram recolhidos com recurso às educadoras de infância e da participação e barreiras ambientes com recurso aos pais. Informações sociodemográficas também foram recolhidas. Neste estudo, participaram 40 educadoras de infância e 116 crianças (e os seus pais), das quais 42 eram elegíveis e tinham apoio da Educação Especial e/ou do Sistema Nacional de Intervenção Precoce para a Infância. Os resultados indicaram que as crianças elegíveis e com apoio apresentam níveis mais baixos de funcionalidade, participam menos frequentemente e estão menos envolvidas nas atividades de casa e da comunidade e que os seus pais percebem mais barreiras ambientais nos contextos. Os resultados foram analisados e discutidos à luz do Modelo Biopsicossocial.
\end{abstract}

PALAVRAS-CHAVE: barreiras ambientais, inclusão social, participação

Participation is a multidimensional concept (Almqvist et al., 2007) defined by the World Health Organization (2007) as "involvement in life situations" (p. 9). The concept of participation is related to involvement in daily life activities, of play and socialization with peers, allowing the child to perform different roles (Almqvist et al., 2007). This way, it requires that the child has a diverse range of experiences, in multiple situations, in which he/she can interact with different people. Thus, for children to experience high levels of participation, they need to be included in different physical and social contexts and to participate in diversified activities (Eriksson et al., 2007). The present study aims to document the participation of children from three to five years old in activities at home and in the community setting

*E-mail: anaguichard@fpce.up.pt

- Submetido: 10/04/2017; Revisado: 21/01/2020; Aceito: 07/05/2020. 
and the environmental barriers that are encountered in these settings, comparing children with and without disability.

According to Almqvist and colleagues (2007), the promotion of positive functioning, learning and mastery occurs through a process of involvement, participation and flow experiences, related to the motivation and satisfaction of the child, in interaction with the environment. In this sense, the concept of participation has been studied in the scientific literature for being considered a pivotal factor promoting development, with influence on learning. Furthermore, participation has shown a positive impact on health and well-being (Law, 2002), independence, school performance and social inclusion of children and young people with disabilities (Simeonsson et al., 2001). In fact, participation has been considered an operationalization of transactions between the child and the environment, with positive results in terms of health and well-being, development and learning (Imms \& Granlund, 2014; Imms et al., 2017).

The concept of participation and its definition has been the target of intense debate in the scientific field (Coster \& Khetani, 2008; Granlund, 2013). However, there is some consensus in its operationalization in two dimensions: the frequency of attending activities in natural contexts and the child's level engagement in these activities (Granlund, 2013; Imms \& Granlund, 2014; Imms et. al, 2017). Both dimensions have been portrayed as fundamental in child development, especially in the early ages (Aydoğan et al., 2015).

Visions of human development have evolved from unidirectional and linear perspective, advocating the unique influence of nature or the environment, to multidirectional, transactional and dynamic perspectives, which consider the individual as an agent and result of mutual influences of biological and social factors over time (Sameroff, 2010). Sameroff (2010) stresses that in order to study the developmental trajectories of the human being in an integrated and comprehensive way, four models should be considered. First, the author refers to a model of personal change, necessary to understand the acquisition of progressively more complex skills, from childhood to adulthood. Secondly, the contextual model explains the direct or indirect impact of the experiences of the developing person, inserted in multiple social contexts, as Bronfenbrenner (1979) advocates in his Bioecological Theory of Human Development. Thirdly, Sameroff (2010) refers to the regulation model (biological, psychological and social), which adds the perspective of interactive and dynamic systems in the conceptualization of the relationship between the individual and the environment. Finally, the representational model is responsible for the codification and interpretation of experiences in cognitive structures, with progressively higher levels of abstraction.

Considering these four models, Sameroff (2010) developed a Unified Theory of Development. This perspective proposes an interactive relationship between psychological and biological processes, which together form, in an integrated way, the biopsychological system of the individual. The domain of self-regulation, in turn, proposes the interaction of the individual with the different surrounding ecological and social contexts, such as the family, the school, the community, but also political, economic and cultural influences. The domain of representations is present in all the interactive aspects of the model, referring to the beliefs, attitudes and attributions of the child, the family and socio-cultural contexts. Thus, by understanding aspects inherent to the individual and the environment and the relationship between them, this perspective considers the human being as a whole, a developing biopsychosocial entity. Finally, the author adds to the theory the dimension of time, in order to consider the processes of growth, change, both quantitative and qualitative, and the transitions that occur along developmental courses (Sameroff, 2010).

Similarly, the perspective of functioning of the Biopsychosocial Model, operationalised by the International Classification of Functioning, Disability and Health for Children and Youth (ICF-CY; WHO, 2007), has an integrative, contextualized and systemic view of different health perspectives (biological, psychological and social), emphasizing the dynamic relationship between child and environment (Almqvist et al., 2007; Peterson et al., 2010). Thus, it is assumed that variables of the child and variables of the physical and social environment may constitute environmental facilitators, factors that facilitate participation in natural contexts, or environmental barriers, factors which make it difficult or harder to participate (WHO, 2007).

According to the Biopsychosocial Model, in assessmentintervention processes, one must take into consideration: (a) the person and his/her health (physical/mental functions and structures); (b) the environment, the physical, psychological and social elements that, if proving adequate, constitute a facilitator or, on the contrary, if inadequate, represent a barrier; and (c) the reciprocal interaction between these elements, resulting in the concepts of participation (which varies from complete to restricted) and performance of activities (which varies from complete to limited) (Felgueiras, 2009).

The World Health Organization defines, within the ICF-CY, functioning as an umbrella concept, i.e., a comprehensive construct that encompasses (1) body functions and structures (changes in physiological systems or anatomical structures), (2) activities and participation (the execution of tasks in a natural context - the notion of performance - or standardized - the notion of capacity). On the other hand, disability is conceptualised, according to the same metaphor, as another umbrella term that encompasses (1) disabilities (deviations, losses or problems in body functions or structures), (2) limitations of the activity and restrictions in participation (difficulties or problems in achieving goals) (WHO, 2007). In this sense, the concept of disability integrates biological, psychological and social aspects in a contextualized and systemic way, emphasizing the dynamic relationship between the individual and the environment (Almqvist et al., 2007).

The inclusion of children and youth with disabilities in daily life contexts is assumed by international guidelines as 
a fundamental human right (Graham, 2014). Recommended practices for Early Childhood Intervention by the Division for Early Childhood (2014) emphasize the promotion of child participation through family-centered interventions in natural and inclusive environments and claim that these interventions should be focused on making adaptations and/or changes in physical and social environments (Division for Early Childhood, 2014). Furthermore, practices recommended by the European Agency for Special Needs and Inclusive Education (2014) consider as priorities the elimination of barriers and the provision of services and support that enhance "the continuous involvement of students and their families in educational experiences" (p. 31).

From 2008 to 2018, Portuguese legislation on the inclusion of children and youth with disabilities included a focus on their right to participation. Decree-Law 3/2008 (amended in 2018) was aimed at children and youth, aged between three and eighteen years old, with "significant limitations in terms of activity and participation in one or more areas of life, resulting from functional and structural changes of a permanent nature" (p. 155). This document included specific support measures in the educational system that aimed to "ensure their greater participation in the activities of each group or class and of the school community in general" (p. 155). In the context of each student's Individual Education Plan (IEP), the ICF model (WHO, 2007) was used to develop a functioning profile, which contained not only functioning indicators, but also "environmental factors that act as facilitators or barriers to the student's activity and participation in school life" (p. 157).

Decree-law 281/2009, prepared in the context of the creation of a National System of Early Intervention in Childhood and still in force, was affirmed as "a political instrument of greater scope in the implementation of the right to social participation" and considers a political priority "to ensure the right to participation and social inclusion for all" (p. 7298). This legislation declares the provision of integrated early intervention support services of a preventive and rehabilitative nature, for children from 0 to 6 years of age, and has as its main objective "to ensure conditions for the development of children with body functions or structures that limit personal and social growth and their participation in typical activities for their age, as well as for children at serious risk of developmental delay" (p. 7298). An Individual Early Intervention Plan (PIIP) is created with and for the family, taking into account "the child's development potential, along with the changes that need to be made to the environment in order for this potential to be asserted" (p. 7298).

However, current literature documents that children with disabilities participate less frequently and with lower levels of engagement in activities at home and in the community setting than children without disabilities and that their parents identify more barriers and less environmental support in both contexts (Anaby et al., 2014; Bedell et al., 2013; Law et al., 2013; Lim et al., 2016; Kang et al., 2017). Moreover, the presence of a disability is a factor that negatively influences participation, particularly in terms of independence, child pleasure and parental satisfaction (Rosenberg et al., 2013).

Therefore, the main goal of the present study is to explore the patterns of participation of children between three and five years at home and in the community setting, comparing children eligible and with support of Special Education, by Decree-Law 3/2008, and/or Early Childhood Intervention, by Decree-Law 281/2009, and ineligible children without support. The present study aims to describe and document the differences between these two groups of children, regarding (1) levels of functioning, (2) levels of participation (in terms of frequency of participation and involvement) in the routines and activities of home and community settings, and (3) the environmental barriers perceived by the children's parents in both contexts.

\section{METHOD}

\section{Participants}

Participants in this study were 116 children from the Greater Metropolitan Area of Porto, 42 of whom were eligible and had support from Special Education and/or Early Childhood Intervention. Of the 116 children in the sample, 83 were male. The children were at least 36 months ( 3 years) and at most 65 months (5 years 5 months) $(M=52.64 ; S D$ $=6.38$ ). The diagnoses of the eligible children, supported by Special Education and/or Early Childhood Intervention, were diverse and included Global Developmental Delay, Autism Spectrum Disorders, Cerebral Palsy, Down Syndrome, Language Delay, Hyperactivity, Hearing Deficit and rare syndromes such as Kabuki's Syndrome, Costello's Syndrome and Cri-du-chat. Of the 42 eligible children, 34 were male. The higher prevalence of males in the group of children with disabilities is similar to previous studies (Lai et al., 2012; Grande, 2013), which report a higher number of boys with disabilities in their samples.

Children, families and preschool teachers were recruited as part of a larger project about children's engagement in inclusive early childhood education settings. For this project, 524 children from 42 kindergarten rooms were contacted and 365 children were allowed to participate by their parents or legal representatives. One hundred and sixteenchildren agreed to participate in the current study. In each of the preschool classes, 1 or 2 children with disability and 2 children without disability were selected by convenience.

The information was collected using the mother as the key informant in 94 families, the father in 10 families, both 
(father and mother) in 11 families and another significant element for the child in only one family of the sample (the grandmother).

Mothers were aged from 23 to 47 years old $(M=35.59$; $S D=5,359)$ and fathers were aged 25 to $64(M=38.02$; $S D=6,584)$. On average, parents completed 10 years of schooling $(M=9.60 ; S D=3.44)$ and mothers completed 11 years of schooling $(M=10.60 ; S D=3.30)$. The families' monthly incomes varied from less than $500 €$ to more than $2500 €$, with $62.9 \%$ of families having monthly incomes less than or equal to $1250 €$.

Preschool teachers were all female and had on average 50 years of age $(M=49.79 ; S D=6.70), 16$ years of schooling $(M=16.10 ; S D=0.45)$ and 25 years of experience working in preschool settings $(M=25.46 ; S D=7.24)$.

\section{Measures}

Assessment of child functioning. In order to document child functioning, six items from the Matrix for Assessment of Activities and Participation (MAAP; Castro et al., 2013) were selected, corresponding to six of the Code Sets for the age groups 0 to 3 years and 3 to 5 years of the WHO ICF-CY Developmental Code Sets (Ellingsen \& Simeonsson, 2011). These were completed by the preschool teacher for each of the participating children.

The MAAP (Castro et al., 2013) was developed with reference to the taxonomy of the ICF-CY (2007) and allows to establish a profile of child functioning in specific dimensions of the ICF-CY Activities and Participation and Environmental Factors (Castro \& Pinto, 2015; WHO, 2007). It is a measure of observation and assessment of child functioning, for children between 2 and 6 years old, and of the surrounding environmental factors, in natural contexts (Castro \& Pinto, 2015).

The WHO ICF-CY Developmental Code Sets (Ellingsen $\&$ Simeonsson, 2011) was based on the domains of the ICFCY, namely Body Functions, Activities and Participation and Environmental Factors (WHO, 2007), in order to facilitate the documentation of the child functioning, with reference to the ecological model, from a multidimensional and multidisciplinary perspective. The final version consists of a reduced number of codes for each domain of ICF-CY (WHO, 2007), considered essential for each developmental period (Ellingsen, 2011).

In the final version of the measure used in this study, the preschool teacher would rate the child's performance in typical activities in a scale from 1 to 5,1 corresponding to Not able and 5, Without any difficulty, for each functioning dimension.

Measure to document child participation and environmental barriers. In order to document child participation and the perception of environmental barriers at home and in the community setting, an adapted version of the Young Children's Participation and Environment Measure
(YC-PEM; Khetani et al., 2013) was used. In each type of activity at home and in the community setting, examples are provided to caregivers and two dimensions of child participation are evaluated: (1) the frequency of participation (8-point scale, in which 0 means Never and 7, Once or more times a day) and (2) the level of involvement (5-point scale, in which 0 means Doesn't participate, 1 means Not very involved and 5, Very involved).

At the end of the set of questions about participation in each setting, caregivers assess the impact of different environmental factors (e.g., physical layout of the context, requirements of activities, legislation and policies) and resources (e.g., transport, information, time and income). The impact of environmental factors on participation is assessed on a 3-point scale, in which 1 means Absence of barriers/usually helpful and 3, Usually difficult. In turn, the impact of environmental resources on participation is assessed on a 3-point scale, in which 1 means No need/ usually yes and 3 , Usually no.

The final adapted version of the instrument was completed together with the father and/or mother for each child.

Sociodemographic questionnaire. Sociodemographic information about the child and his/her family was collected through a short questionnaire completed together with the father and/or mother of the child. The questionnaire included questions about the child (age, sex) and the parents (age of parents, occupation, educational level and monthly household income).

\section{Procedure}

Data collection. The Portuguese National Data Protection Authority (no. 16785/2015) and the Committee for Monitoring Studies in Education Settings of the General Direction of the Ministry of Education (no. 0535000001) approved this study. Separate ethics approval from the Faculty of Psychology and Educational Sciences (University of Porto) was not required. In total, 80 school clusters from the Great Metropolitan Area of Porto were contacted and invited to participate in the project. Schools had to have inclusive preschool classes, with one or more children identified by Decree-Law 3/2008 (Special Education) and/or Decree-Law 281-2009 (Early Childhood Education).

An informed consent for the participation of each child in the research project was obtained from the families, explaining the main objectives of the study and ethical procedures. The participation of the preschool teachers, families and children in the study was voluntary and informed, and the participants had the right to ask for additional clarifications if requested. The confidentiality and anonymity of the information provided by the families and preschool teachers and of all the collected data was always ensured. 
The data collection process occurred between February and June 2016. In a first phase, the measure of documentation of the child functioning was completed in a meeting with the preschool teacher. Then, the parents (or main caregivers) of the children were contacted to schedule a meeting at school or at home, depending on the availability of the family and the setting. At the meeting, the socio-demographic questionnaire and the adapted Portuguese version of YC-PEM (Khetani et al., 2013) were completed with the families.

Data analysis. IBM SPSS Statistics for Windows, version 22 , was used to perform all data analysis. In a first stage, descriptive analyses (frequencies, means and standard deviations) of child variables (gender, age, disability status) and parents' variables (age, schooling and monthly income) were performed. Then, descriptive analyses (frequency, means and standard deviations) were carried out for children's participation in activities at home and in the community setting and for perceived environmental barriers by parents.

Then, in order to analyse the data obtained by the adapted version of the YC-PEM (Khetani et al., 2013), composite variables were created, as suggested in Bedell and colleagues (2013). Thus, it was necessary to test the consistency of the items that would constitute each variable. We calculated the Cronbach's alpha, the most frequently used strategy to assess the consistency of a measure (Field, 2015).

In a first instance, it becomes relevant to explain that the items related to basic care routines at home were not considered for the calculation of the Cronbach's alpha, since their variability was null, except in the routine related to Getting clean (e.g., wash or wipe hands and face, taking a bath). Thus, the parents indicated that all children participated in these routines every day. However, the involvement in these daily routines was contemplated in the composite variable of involvement in the home setting, as it varied according to the routine.
After a preliminary descriptive analysis of the frequencies of each of the items, it was possible to conclude that more than $65 \%$ of the children had never participated in the following community activities: (1) Organised activities (which included, for example, art and music, groups for learning about nature, scouts), (2) Organised physical activities (which included, for example, dance classes, swimming, football, horse riding classes) and (3) Religious activities or meetings (which included, for example, going to church or another place of worship). Therefore, we decided not to consider the frequency of participation and involvement in these community activities in the scales related to the community setting.

Table 1 and 2 include the description of the composite variables and the respective Cronbach's alphas, that varied between $\alpha=0.58$ and $\alpha=0.75$. The descriptive results (mean, standard deviation and amplitude) of frequency of participation, involvement and environmental barriers at home (Table 1) and in the community (Table 2) are also presented. The activities and the specific environmental barriers included in each composite variable are presented in Table 1 (home setting) and Table 2 (community setting).

Subsequently, the two groups of children $\left(\mathrm{C}_{1}-\right.$ children eligible and supported by Special Education and/or Early Childhood Intervention - and $\mathrm{C}_{2}$ - children non-eligible and not supported by these services) were compared in terms of functioning (for the overall score and each of the six Developmental Code Sets), participation at home and in the community setting and the parents' perception of environmental barriers. Given the size of the groups as well as the differences in size between the groups of children, the nonparametric Mann-Whitney test was used, corresponding to the $t$ test for independent samples.

The results were interpreted based on the magnitude of differences between groups, calculated by converting the $\mathrm{Z}$ values into $r$ values, using the formula suggested by Rosenthal (1991) and recommended by Field (2015).

\section{RESULTS}

\section{Functioning profile}

According to the preschool teachers, children eligible and with support of Special Education and/or Early Childhood Intervention $-\mathrm{C}_{1}-$ had lower levels of functioning ( $M d n$ $=16.00)$ than children non-eligible and without additional support $-\mathrm{C}_{2}-(M d n=23.00), U=2.679,00, z=6.37, p$ $<.001, r=0.59$. A large effect size is observed, as $r>.50$ (Field, 2015).

In Figure 1, differences between the two groups can be verified for the six Developmental Code Sets. We found statistically significant differences between the two groups for the six Developmental Code Sets, with effects sizes from small to large. According to preschool teachers, the largest differences are observed between children with and without additional support in the code sets related to focusing attention [b140] and preschool education [d815] and the smallest differences in the Developmental Code Sets related to acquiring concepts [d137] and performing a single task [d210].

\section{Participation and involvement at home and in the community}

According to parents, children eligible and with support of Special Education and/or Early Childhood Intervention - 
Table 1

Description of variables for participation and environmental barriers at home

\begin{tabular}{|c|c|c|c|c|c|c|c|c|c|c|c|}
\hline \multicolumn{4}{|c|}{ Frequency of participation } & \multicolumn{4}{|c|}{ Involvement } & \multicolumn{4}{|c|}{ Environmental barriers } \\
\hline \multicolumn{4}{|c|}{ Cronbach $\alpha=.65$} & \multicolumn{4}{|c|}{ Cronbach $\alpha=.69$} & \multicolumn{4}{|c|}{ Cronbach $\alpha=.65$} \\
\hline $\begin{array}{c}n \\
115\end{array}$ & $\begin{array}{c}M \\
5.70\end{array}$ & $\begin{array}{c}S D \\
1.10\end{array}$ & $\begin{array}{c}\text { Range } \\
3.11-7.56\end{array}$ & $\begin{array}{c}n \\
116\end{array}$ & $\begin{array}{c}M \\
3.77\end{array}$ & $\begin{array}{c}S D \\
\mathbf{0 . 7 3}\end{array}$ & $\begin{array}{c}\text { Range } \\
2.00-4.92\end{array}$ & $\begin{array}{c}N \\
116\end{array}$ & $\begin{array}{c}M \\
1.18\end{array}$ & $\begin{array}{l}S D \\
0.21\end{array}$ & $\begin{array}{c}\text { Range } \\
1.00-2.08\end{array}$ \\
\hline \multicolumn{4}{|c|}{$\begin{array}{c}\text { Items } \\
\text { (8-point scale, in which } 0 \text { means Never and } \\
\text { 7, Once or more times a day) }\end{array}$} & \multicolumn{4}{|c|}{$\begin{array}{c}\text { Items } \\
\text { (5-point scale, in which } 0 \text { means Doesn't } \\
\text { participate, } 1 \text { means Not very involved and } 5, \\
\text { Very involved) }\end{array}$} & \multicolumn{4}{|c|}{$\begin{array}{l}\text { Items } \\
\text { (3-point scale, in which } 1 \text { means } \text { Absence } \\
\text { of barriers/usually helpful and 3, Usually } \\
\text { difficult) }\end{array}$} \\
\hline \multicolumn{4}{|c|}{$\begin{array}{l}\text { Arts, stories, music } \\
\text { (e.g., colouring, reading books) }\end{array}$} & \multicolumn{4}{|c|}{$\begin{array}{l}\text { Arts, stories, music } \\
\text { (e.g., colouring, reading books) }\end{array}$} & \multicolumn{4}{|c|}{$\begin{array}{l}\text { Physical layout } \\
\text { (e.g., organized, open, safe space at home) }\end{array}$} \\
\hline \multicolumn{4}{|c|}{$\begin{array}{l}\text { Screen time } \\
\text { (e.g., films, tv, tablet) }\end{array}$} & \multicolumn{4}{|c|}{$\begin{array}{l}\text { Screen time } \\
\text { (e.g., films, tv, tablet) }\end{array}$} & \multicolumn{4}{|c|}{$\begin{array}{l}\text { Sensory qualities of home } \\
\text { (e.g., amount/type of sound, light, smell) }\end{array}$} \\
\hline \multicolumn{4}{|c|}{$\begin{array}{l}\text { Play and games } \\
\text { (e.g., with animals, dolls, cars) }\end{array}$} & \multicolumn{4}{|c|}{$\begin{array}{l}\text { Play and games } \\
\text { (e.g., with animals, dolls, cars) }\end{array}$} & \multicolumn{4}{|c|}{$\begin{array}{l}\text { Physical demands of typical activities } \\
\text { (e.g., strength, endurance, coordination) }\end{array}$} \\
\hline \multicolumn{4}{|c|}{$\begin{array}{l}\text { Cleaning up } \\
\text { (e.g., picking up toys) }\end{array}$} & \multicolumn{4}{|c|}{$\begin{array}{l}\text { Cleaning up } \\
\text { (e.g., picking up toys) }\end{array}$} & \multicolumn{4}{|c|}{$\begin{array}{l}\text { Cognitive demands of typical activities } \\
\text { (e.g., attention, problem-solving) }\end{array}$} \\
\hline \multicolumn{4}{|c|}{$\begin{array}{l}\text { Preparing meals } \\
\text { (e.g., setting the table) }\end{array}$} & \multicolumn{4}{|c|}{$\begin{array}{l}\text { Preparing meals } \\
\text { (e.g., setting the table) }\end{array}$} & \multicolumn{4}{|c|}{$\begin{array}{l}\text { Social demands of typical activities } \\
\text { (e.g., communication, interaction) }\end{array}$} \\
\hline \multicolumn{4}{|c|}{$\begin{array}{l}\text { Taking care of other family members (e.g., } \\
\text { helping siblings) }\end{array}$} & \multicolumn{4}{|c|}{$\begin{array}{l}\text { Taking care of other family members (e.g., } \\
\text { helping siblings) }\end{array}$} & \multicolumn{4}{|c|}{$\begin{array}{l}\text { Relationship with family members (e.g., } \\
\text { parents, siblings) }\end{array}$} \\
\hline \multicolumn{4}{|c|}{$\begin{array}{l}\text { Laundry and dishes } \\
\text { (e.g., load, unload) }\end{array}$} & \multicolumn{4}{|c|}{$\begin{array}{l}\text { Laundry and dishes } \\
\text { (e.g., load, unload) }\end{array}$} & \multicolumn{4}{|c|}{$\begin{array}{l}\text { Attitudes and actions of babysitters, therapists, } \\
\text { and other professionals at home }\end{array}$} \\
\hline \multicolumn{4}{|c|}{$\begin{array}{l}\text { Celebrations at home } \\
\text { (e.g., birthday parties) }\end{array}$} & \multicolumn{4}{|c|}{$\begin{array}{l}\text { Celebrations at home } \\
\text { (e.g., birthday parties) }\end{array}$} & \multicolumn{4}{|c|}{$\begin{array}{l}\text { Policies (e.g., parental leave, time off, work } \\
\text { hours) }\end{array}$} \\
\hline \multirow{5}{*}{\multicolumn{2}{|c|}{$\begin{array}{l}\text { Guests at home } \\
\text { (e.g., family/friends) }\end{array}$}} & & & \multicolumn{4}{|c|}{$\begin{array}{l}\text { Guests at home } \\
\text { (e.g., family/friends) }\end{array}$} & $\begin{array}{l}\text { Services } \\
\text { (e.g., pr }\end{array}$ & $\begin{array}{l}\text { ome } \\
\text { ionals, } \mathrm{b}\end{array}$ & tters) & \\
\hline & & & & $\begin{array}{l}\text { Resting } \\
\text { (e.g., sle }\end{array}$ & g routine & & & $\begin{array}{l}\text { Supplie: } \\
\text { (e.g., tc }\end{array}$ & $\begin{array}{l}\text { he home } \\
\text { food, cl }\end{array}$ & & \\
\hline & & & & $\begin{array}{l}\text { Persona } \\
\text { (e.g., dr }\end{array}$ & g, washir & & & $\begin{array}{l}\text { Informa } \\
\text { (e.g., ab }\end{array}$ & ctivities, & ces, pr & rams) \\
\hline & & & & $\begin{array}{l}\text { Getting } \\
\text { (e.g., tal }\end{array}$ & a bath) & & & $\begin{array}{l}\text { Time (tc } \\
\text { home) }\end{array}$ & port you & partic & ation at \\
\hline & & & & $\begin{array}{l}\text { Meals } \\
\text { (e.g., ea }\end{array}$ & breakfast & ch and & ner) & $\begin{array}{l}\text { Money } \\
\text { home) }\end{array}$ & ipport yo & ild par & ipation at \\
\hline
\end{tabular}

$\mathrm{C}_{1}$ - participate less frequently in routines and activities at home $(M d n=5.44)$ than children non-eligible and without additional support $-\mathrm{C}_{2}-(M d n=6.10), U=2.134,50, z=$ $3.39, p<.001, r=0.32-$ moderate effect size.

According to parents, children eligible and with support of Special Education and/or Early Childhood Intervention $\mathrm{C}_{1}$ - participate less frequently in activities in the community $(M d n=3.19)$ than children non-eligible and without additional support $-\mathrm{C}_{2}-(M d n=3.63), U=1.826,50, z=$ $1.99, p=.046, r=0.19-$ small effect size.

Concerning the levels of involvement in routines and activities at home, parents reported that children eligible and with support of Special Education and/or Early Childhood Intervention $-\mathrm{C}_{1}-$ were less involved $(M d n=3.54)$ than children non-eligible and without additional support $-\mathrm{C}_{2}$ - $(M d n=4.00), U=2.180,50, z=3.50, p<.001, r=0.32$ - moderate effect size.

Moreover, according to the parents' perspective, children eligible and with support of Special Education and/ or Early Childhood Intervention $-\mathrm{C}_{1}-$ were less involved in activities in the community $(M d n=2.63)$ than children non-eligible and without additional support $-\mathrm{C}_{2}-(M d n=$ 3.63), $U=2.131,00, z=3.21, p=.001, r=0.30$ - moderate effect size. 
Table 2

Description of variables for participation and environmental barriers in the community

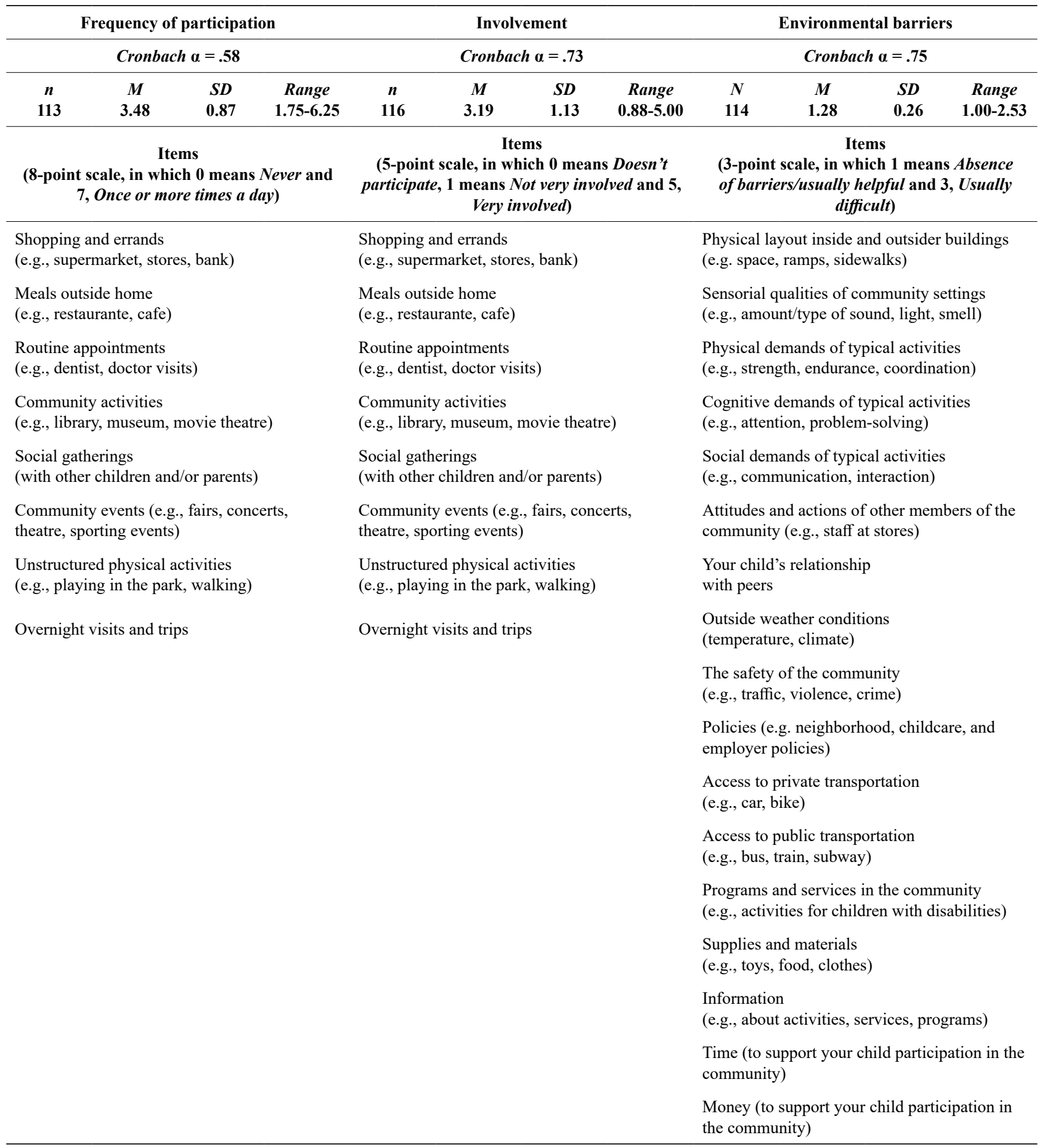

\section{Perceived environmental barriers by the parents}

Parents of children eligible and with support of Special Education and/or Early Childhood Intervention - $\mathrm{C}_{1}-$ perceive more environmental barriers at home $(M d n=1.29)$ than parents of children non-eligible and without additional support $-\mathrm{C}_{2}-(M d n=1.08), U=747.000, z=-4.81, p<$ $.001, r=-0.45-$ large effect size.

Parents of children eligible and with support of Special Education and/or Early Childhood Intervention $-\mathrm{C}_{1}-$ also perceive more environmental barriers in the community $(M d n=1.45)$ than parents of children non-eligible and without additional support $-\mathrm{C}_{2}-(M d n=1.12), U=572.500$, $z=-5.48, p<.001, r=-0.51-$ large effect size. 


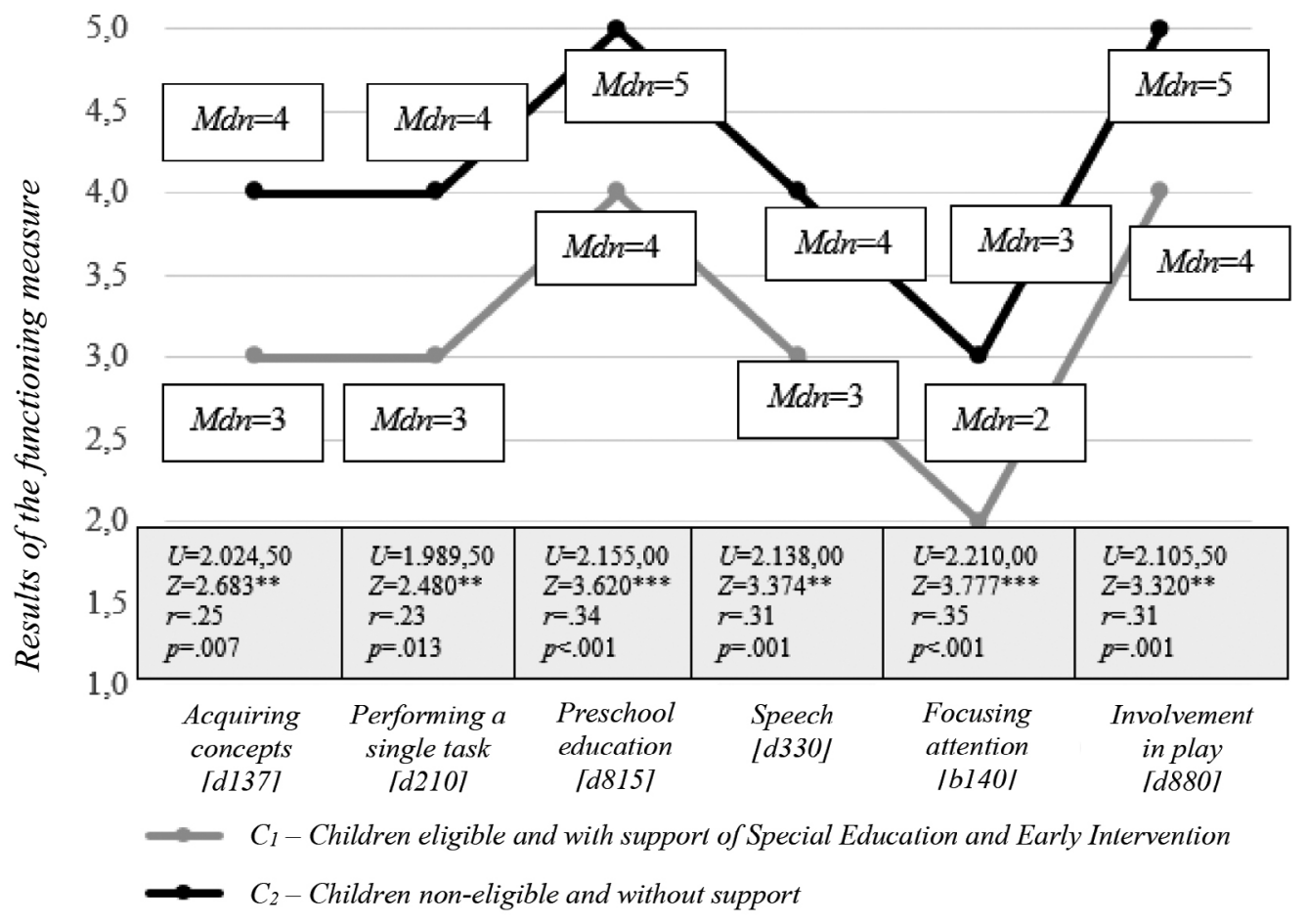

${ }^{*} p<.05 ; * * p<.01 ; * * * p<.001$

Figure 1. Difference between children $\left(\mathrm{C}_{1}\right.$ e $\left.\mathrm{C}_{2}\right)$ in their functioning profile

\section{DISCUSSION}

The results obtained in this exploratory study contribute to the documentation of the levels of functioning, participation of children between three and five years old at home and in the community, and environmental barriers perceived by their parents. In this study, we aimed to describe and document differences between children eligible and supported by Special Education and/or Early Childhood Intervention and children noneligible and without additional support, in three levels: (1) functioning - the child's health and developmental status; (2) frequency of participation and involvement in routines and activities in both settings - participation at home and in the community; and (3) perception of environmental barriers by parents Environment at home and in the community.

Thus, we decided to organize the discussion of results according to the Biopsychosocial Model of the ICF-CY (WHO, 2007), as it considers: (a) the child and his/her health - health condition and body functions and structures; (b) the environment - environmental and personal factors; and (c) the interaction between these aspects, from which arises the activities and participation of the child in daily contexts (Felgueiras, 2009).

\section{Child Health and Developmental Status}

First, results refer that children eligible and supported by Special Education and/or Early Childhood Intervention had lower levels of functioning, overall and in all six Developmental Code Sets, when compared with children non-eligible and without support, according to preschool teachers.

The largest differences between children with and without additional support were observed in the Developmental Code Sets related to focusing attention [b140 - The child can focus for an amount of time adequate to his/her age range] and early childhood education [d815 - The child is able to be involved in daily routines at preschool in an adequate manner]. On the other hand, the smallest differences between the two groups of children were registered in the Developmental Code Sets related to acquiring concepts [d137 - The child can understand and use basic concepts, such as above, bellow, next to, fast, slowly] and performing a single task [ $\mathrm{d} 210$ - The child can perform a single task or respond to a single communication]. The profile also included the child's abilities to play [d880] and to participate in conversations, using a discourse adequate to his/her age range [d330].

Thus, instead of categorizing children based on their etiology, we outlined a holistic profile of their developmental functioning, emphasizing the differences in their performance in different areas. We were able to highlight both their greatest limitations and difficulties, as well as their potential and strengths. This way, the ICF-CY 
approach (WHO, 2007) calls into question the medical model, centered on aspects of the child's biosystem. In this sense, as Felgueiras (2009) states, it becomes urgent that assessment-intervention processes consider both the nature and severity of the functional limitations of the child, as well as his/her participation in daily life settings and the contextual, proximal and distal factors, through the identification of barriers and facilitators. This way, more than valuing the diagnosis of children, aspects of a nosological nature from the biomedical perspective, the study places focus on the functional evaluation of activities and participation. These results contribute to the affirmation of the biopsychosocial perspective, as they suggest that the diagnosis or categorization of children by etiology does not provide relevant information on functioning - the interaction between the child (with a health and developmental status) and contextual factors (environmental and personal) (WHO, 2007).

In future studies, we recommend that the functioning profile would be more complete, including a wider range of areas and complementing the views of the preschool teachers with the perspectives of parents and the observation of the child in context. Moreover, literature has highlighted that children with the same categorical designation or diagnosis have different profiles and different degrees of disability, at different levels (Grande, 2013). Thus, it would be important in future investigations to analyse to what extent children could be organised into subgroups, based on their levels of functioning. This way, it would be possible to ascertain whether there are children who, although not identified by Special Education and/or Early Childhood Intervention services, have limitations in performing activities or restrictions in their participation and who would benefit from intervention.

\section{Participation}

After comparing children based on their functioning profile in six Developmental Code Sets, we sought to understand to what extent their participation (in terms of frequency of participation and involvement), at home and in the community, differed, according to the parents. It was possible to observe that, according to the parents' report, eligible children and with support from Special Education and/or Early Childhood Intervention participate less frequently and are less involved in routines and activities at home and in the community, than non-eligible children, without additional support. It is important to recall that the activities at home included playing and games, collaboration in domestic chores and celebrations or reception of family and friends at home. On the other hand, community activities included shopping and errands, going to restaurants or café, nature and cultural activities, medical appointments, social gatherings, events, unstructured physical activities and trips. These results are consistent with studies conducted with families with school-age children and youth, which revealed that children with disabilities have lower levels of frequency of participation and involvement at home and in the community (Anaby et al., 2014; Bedell et al., 2013; Law et al., 2013). This way, children with disabilities do not have access to the same activities and experiences as their peers without disabilities and, when they do, they have lower levels of involvement.

Notwithstanding, it would be valuable to develop additional exploratory studies on participation at home and in the community setting using the Portuguese adapted version of the YC-PEM (Khetani et al., 2013) to assess the cultural and ecological validity of the instrument used. Moreover, we suggest that, through a qualitative methodology, information on the experiences of participation of Portuguese families in their daily life contexts with children with and without disabilities are collected.

In addition, cross-country comparison studies are considered essential, as there already exists literature that attributes relevance to the country of residence in explaining the participation levels of children with disabilities (Fauconnier et al., 2009; Ullenhag et al., 2012). Thus, it is important to understand how levels of participation of Portuguese children are situated in the European context, relating results with the legislative measures of each country.

\section{Environment}

Finally, we studied the environmental dimension of the ICF-CY Biopsychosocial Model (WHO, 2007) - the set of physical, social and psychological elements, which, if appropriate, constitutes facilitators or, on the contrary, if inadequate, represents barriers to participation. It was possible to verify that the parents of eligible children with the support of Special Education and/or Early Intervention perceive more environmental barriers, in both contexts studied (home and community). This evidence is consistent with the studies carried out by Bedell and colleagues (2013) and by Law and colleagues (2013) with families of school aged children and youth, with and without disabilities.

These results provide significant evidence about the importance of modifying specific environmental factors to promote child participation in daily contexts. When referring to the identification of barriers in the contexts by parents, the measure used takes into account the immediate physical and social characteristics of the environments (the physical disposition of the context, the requirements of the activities carried out, the interpersonal relationships), situated at a more proximal, microsystemic level, and macroeconomic variables (available information, legislation and policies), situated at a more distal, macrosystemic level. 


\section{CONCLUSIONS}

In conclusion, the present study revealed that children eligible and with support from Special Education and/or Early Intervention have lower levels of functionality, according to their preschool teachers, and experience restrictions in their participation at home and in the community setting, according to the parents' report, when compared to noneligible children and without additional support. In fact, the parents of children with support of Special Education and/or Early Intervention perceive more environmental barriers in the contexts and their children have fewer opportunities for participation, i.e., they participate less frequently in these contexts. Moreover, when they participate, these children are less involved in home and community activities. Thus, it becomes essential that legislative policies ensure the universal right to participation and inclusion of all children in their natural contexts, in the activities in which their peers of the same age group participate in, as recommended by international guidelines in this area (Graham, 2014).
Thus, assessment-intervention processes, developed in collaboration with families, should consider both the nature and severity of the child's functioning limitations, as well as his/her participation in daily life contexts and contextual, proximal and distal factors, through the identification of barriers and facilitators. This way, for all children to fulfill their developmental potential, we should aim at an increase in the frequency, variety and quality of daily learning opportunities in socially and culturally significant activities for the child and the family.

The promotion of children's fundamental rights in the early years of life, in a society with equal opportunities, is a fundamental investment that will contribute to the health and education of the population, to the security and harmonious functioning of communities and, ultimately, to the self-sustainability and prosperity of all countries (Shonkoff, 2015).

\section{ACKNOWLEDGMENTS}

The current study was funded by Fundação para a Ciência e Teconologia under Grant SFRH/BD/111211/2015. The authors would like to dedicate this work to Professor Ana
Isabel Pinto and acknowledge her friendship, wisdom and contributions for research in Early Childhood Intervention.

\section{REFERENCES}

Aydoğan, C., Farran, D. C., \& Sağsöz, G. (2015). The relationship between kindergarten classroom environment and children's engagement. European Early Childhood Education Research Journal, 23(5), 604-618. doi:10.1080/1350293X.2015.1104036

European Agency for Special Needs and Inclusive Education (2014). Five key messages for inclusive education. Putting theory into Pratice. Denmark: European Agency for Special Needs and Inclusive Education.

Almqvist, L., Uys, C. J. E., \& Sandberg, A. (2007) Patterns of engagement of children with and without developmental delay. Journal of Policy and Practice in Intellectual Disabilities, 3(1), 65-75. doi:10.1111/j.1741-1130.2006.00054.x

Anaby, D., Law, M., Coster, W., Bedell, G., Khetani, M., Avery, L., \& Teplicky, R. (2014). The mediating role of the environment in explaining participation of children and youth with or without disabilities across home, school and community. Archives of Physical Medicine and Reabilitation, 95, 908-917. doi:10.1016/j.apmr.2014.01.005

Bedell, G., Coster, W., Law, M., Liljenquist, K., Kao, Y.C., Teplicky, R., Anaby, D., \& Khetani, M. (2013). Community Participation, Support and Barriers of School-Age Children With and Without Disabilities. Archives of Physical Medicine and Rehabilitation, 94, 315-323. doi:10.1016/j.apmr.2012.09.024

Bronfenbrenner, U. (1979). The ecology of human development: Experiments by natural and design. Cambridge: Harvard University Press.

Castro, S., \& Pinto, A. I. (2015). Matrix for assessment of activities and participation: Measuring functioning beyond diagnosis in young children with disabilities. Developmental neurorehabilitation, 18(3), 177-189. doi:10.3109/17518423 .2013 .806963

Castro, S., Pinto, A. I., \& Figueiredo, A. (2013). Matrix of Activities and Participation Evaluation. Unpublished instrument. [Matriz de Avaliação das Atividades e Participação. Instrumento não publicado]. Faculdade de Psicologia e de Ciências da Educação, Universidade do Porto.

Coster, W., \& Khetani, M. A. (2008). Measuring participation of children with disabilities: issues and challenges. Disability and rehabilitation, 30(8), 639-648. doi:10.1080/09638280701400375

Decree-law 281/2009. Creation of a National System for Early Childhood Intervention ["Criação de um Sistema Nacional de Intervenção Precoce na Infância (SNIPI)"]. Diário da República, I Série, N. ${ }^{\circ} 193$, de 6 de Outubro de 2009, pp. 7298-7301.

Decree-law n ${ }^{\circ} 3 / 2008$. Defines the specialised support for preschool, primary and secondary education in the public, private and cooperative sectors, aiming at creating conditions for adequate education processes of students with significative limitations in activity and participation in one or several domains of school life ["Define os apoios especializados a prestar na educação pré-escolar e nos ensinos básico e secundário dos sectores público, privado e cooperativo visando a criação de condições para a adequação do processo educativo às necessidades educativas especiais dos alunos com limitações significativas ao nível da atividade e da participação num ou em vários domínios da vida escolar"]. Diário da República, I Série, N. ${ }^{\circ}$ 4, de 7 de Janeiro de 2008, pp. 154-164. 
Division for Early Childhood. (2014). DEC recommended practices in early intervention/early childhood special education. Retrieved from http://www.dec-sped.org/recommendedpractices.

Ellingsen, K. M. (2011). Deriving developmental code sets from the international classification of functioning, disability and health, for children and youth (ICF-CY). University of North Carolina at Chapel Hill. Unpublished $\mathrm{PhD}$ dissertation.

Ellingsen, K. M \& Simeonsson, R. J. (2011). WHO ICF-CY Developmental Code Sets. Retrieved from http://www. icfcydevelopmentalcodesets.com/

Eriksson, L., Welander, J., \& Granlund, M. (2007) Participation in everyday school activities for children with and without disabilities. Journal of Developmental and Physical Disabilities, 19(5), 485-502. doi:10.1007/s10882-007-9065-5

Fauconnier, J., Dickinson, H. O., Beckung, E., Marcelli, M., McManus, V., Michelsen, S. I., Parkes, J., Parkinson, K.N., Thyen, U., Arnaud, C., \& Colver, A. (2009). Participation in life situations of 8-12 year old children with cerebral palsy: cross sectional European study. The BMJ, 338, 1-12. doi:10.1136/bmj.b1458

Felgueiras, I. (2009). The international classification of functionality, disability and health (ICF) and its contributions to the reconcetualization of disability and disability. In G. Portugal (Org.), Ideas, projects and innovation in the world of childhood: the path and presence of Joaquim Bairrão (pp. 47-62) [A classificação internacional de funcionalidade, incapacidade e saúde (CIF) e seus contributos para a reconcetualização da deficiência e da incapacidade. In G. Portugal (Org.), Ideias, projectos e inovação no mundo das infâncias: o percurso e a presença de Joaquim Bairrão (pp. 47-62)]. Aveiro: Theoria Poiesis Praxis, Universidade de Aveiro.

Field, A. (2015). Discovering statistics using IBM SPSS statistics ( $4^{\text {th }}$ Edition). London: Sage.

Granlund, M. (2013). Participation-challenges in conceptualization, measurement and intervention. Child: care, health and development, 39(4), 470-473. doi:10.1111/cch.12080

Graham, N. (2014). Children With Disabilities. Paper commissioned for Fixing the Broken Promise of Education for All: Findings from the Global Initiative on Out-of-School Children. Montreal: UNESCO Institute for Statistics (UIS).

Grande, C. (2013). Study of the impact of teacher-child interactions on the engagement of children with special educational needs in the context of daycare and kindergarten. [Estudo do impacto das interacções educadora-criança no envolvimento das crianças com necessidades educativas especiais em contexto de creche e de jardim-de-infância]. Lisboa: Fundação Calouste Gulbenkian.

Imms, C., \& Granlund, M. (2014). Participation: Are we there yet.... Australian occupational therapy journal, 61(5), 291292. doi:10.1111/1440-1630.12166

Imms, C., Granlund, M., Wilson, P. H., Steenbergen, B., Rosenbaum, P. L., \& Gordon, A. M. (2017). Participation, both a means and an end: a conceptual analysis of processes and outcomes in childhood disability. Developmental Medicine \& Child Neurology, 59(1), 16-25. doi:10.1111/dmcn.13237

Kang, L. J., Hsieh, M. C., Liao, H. F., \& Hwang, A. W. (2017). Environmental barriers to participation of preschool children with and without physical disabilities. International journal of environmental research and public health, 14(5), 518. doi:10.3390/ijerph14050518

Khetani, M.A., Coster, W., Law, M. \& Bedell, G.M. (2013) Young Children's Participation and Environment Measure (YC-PEM). Fort Collins (CO): Colorado State University.

Law, M. (2002). Participation in the occupations of everyday life. American journal of Occupational Therapy, 56, 640-9. doi:10.5014/ajot.56.6.640 .

Law, M., Anaby, D., Teplicky, R., Khetani, M. A., Coster, W., \& Bedell, G. (2013). Participation in the home environment among children and youth with and without disabilities. The British Journal of Occupational Therapy, 76(2), 58-66. doi:10.4276/030802213X13603244419112

Lim, C. Y., Law, M., Khetani, M., Pollock, N., \& Rosenbaum, P. (2016). Participation in out-of-home environments for young children with and without developmental disabilities. OTJR: occupation, participation and health, 36(3), 112-125. doi:10.1177/1539449216659859

Peterson, D., Mpofu, E., \& Oakland, T. (2010). Concepts and Models in Disability, Functioning, and Health. In Mpofu, E and Oakland, T (Eds.), Rehabilitation and Health Assessment: Applying ICF Guidelines, (pp. 3-26). United States: Springer Publishing Company.

Rosenberg, L., Bart, O., Ratzon, N.Z., \& Jarus, T. (2013) Personal and Environmental Factors Predict Participation of Children With and Without Mild Developmental Disabilities. Journal of Child and Family Studies, 22, 658-671. doi:10.1007/s10826012-9619-8

Rosenthal, R. (1991). Meta-analytic procedures for social research (revised edition). Newbury Park, CA: Sage. doi:10.4135/9781412984997

Sameroff, A. (2010). A unified theory of development: A dialectic integration of nature and nurture. Child development, 81(1), 6-22. doi:10.1111/j.1467-8624.2009

Shonkoff, J.P. (2015). The neurobiology of childhood development and the foundation of a sustainable society. In P. T. M. Marope and Y. Kaga (Eds.), Investing against Evidence: The Global State of Early Childhood Care and Education (pp. 55-71). Paris, UNESCO Publising.

Simeonsson, R.J., Carlson, D., Huntington, G., McMillen, J., \& Brent, J. (2001) Students with disabilities: A national survey of participation in school activities. Disability and Rehabilitation, 23(2), 49-63. doi:10.1080/096382801750058134

Ullenhag, A., Bult, M. K., Nyquist, A., Ketelaar, M., Jahnsen, R., Krumlinde-Sundholm, L., Almqvist, L., \& Granlund, M. (2012). An international comparison of patterns of participation in leisure activities for children with and without disabilities in Sweden, Norway and the Netherlands. Developmental neurorehabilitation, 15(5), 369-385. doi:10.3109/17518423 .2012 .694915

WHO [World Health Organization] (2007). International Classification of Functioning, Disability and Health, Children \& Youth Version: ICF-CY. Geneva, Switzerland: World Health Organization. 